\title{
Anthropogenic impacts on Keshalia River, Eastern Nepal
}

\author{
Jay Narayan Shrestha \\ Department of Zoology, Post Graduate Campus, T.U., Biratnagar, Nepal \\ E-mail: Jaynstha@gmail.com
}

\begin{abstract}
The anthropogenic impact on Keshalia river, especially on fish diversity, is very high. Over fishing with unconventional fishing methods, disposal of domestic and industrial effluents, excess use of pesticides, dumping sites of municipalities, dam construction without fish ladder across the river and mining of sands and gravels are major anthropogenic impacts on the river.
\end{abstract}

Key words: Budhi Khola, Coliform bacteria, Electro fishing, Noorani

\section{Introduction}

Keshalia river comes from Mahabharat mountain. A small tributary called Budhi Khola starts from the upper region Yangsila VDC, Morang. It flows down ward to south through the border of Panbari and Satisale. It runs across the Charkoshe jungle and receives its tributary called Dale Khola. During its course, the Budhi Khola crosses the East-West highway and meets with Gachhiya Khola at Khanar. Later the Budhi Khola crosses DharanBiratnagar high way at Duhabi and flows toward south-west direction which latter is called Keshalia river. The river flows on the border between Sunsari and Morang district. Finally the river flows to south direction toward the India.

Keshalia river flows from west side of Biratnagar Metropolitan City. There are many factories and industries nearby the river. Industrial effluents, drainage from the city and wastes coming from hospitals and municipality are disposed directly or indirectly into the river. In spite of this, no one contributes to the anthropogenic impacts on aquatic fauna, especially fishes of Keshalia river.

The climate of the river is tropical and monsoon. Summer (March-June), rainy (JulyOctober) and winter (November-February) are its three main seasons. Its temperature ranges in between $11.1^{\circ} \mathrm{C}$ and $33.9^{\circ} \mathrm{C}$ in summer and in between $9^{\circ} \mathrm{C}$ to $15.3^{\circ} \mathrm{C}$ in winter. Directly or indirectly, the river receives many pollutants from Panbari, Kerabari, Itahari, Khanar, Duhabi and Biratnagar through its tributaries which receive runoff water and drainage channels coming from cities and villages.

Regarding anthropogenic impacts on rivers, Lae (1995) gave a precious contribution on climatic and anthropogenic effects on fish diversity and fish yields in the central delta of the Niger river. Puff et al. (1997) worked on river conservation and restoration. Cowx (2002) analyzed the threats to freshwater fish conservation and past and present challenges. Bhatnagar et al. (2004) worked on water quality management in aquaculture. Ekubo and Abowei (2011) reviewed some water quality management principles in culture fisheries. Gurung (2012) worked on challenges and opportunities of native fish conservation in Nepal. Bukola et al. (2015) gave consequences of anthropogenic activities on fish and the aquatic environment. 


\section{Materials and Methods}

The river was studied from Panbari, Sunsari District (study area 1) up to $2 \mathrm{~km}$ down the Bramapura, Morang District (study area 2) (Fig. 1) from $1^{\text {st }}$ October, 2015 to $30^{\text {th }}$ September, 2016. The Bramapura (Lat. 26 $26^{\prime} 58.08^{\prime \prime} \mathrm{N}$ and Long. $87^{\circ} 14^{\prime} 42.55^{\prime \prime} \mathrm{E}$, alt. $54 \mathrm{~m}$ $\mathrm{msl}$ ) lies $2 \mathrm{~km}$ west in Biratnagar Metropolitan city 7. Water samples were collected on $30^{\text {th }}$ August, 2016 and analyzed by following APHA (1998).

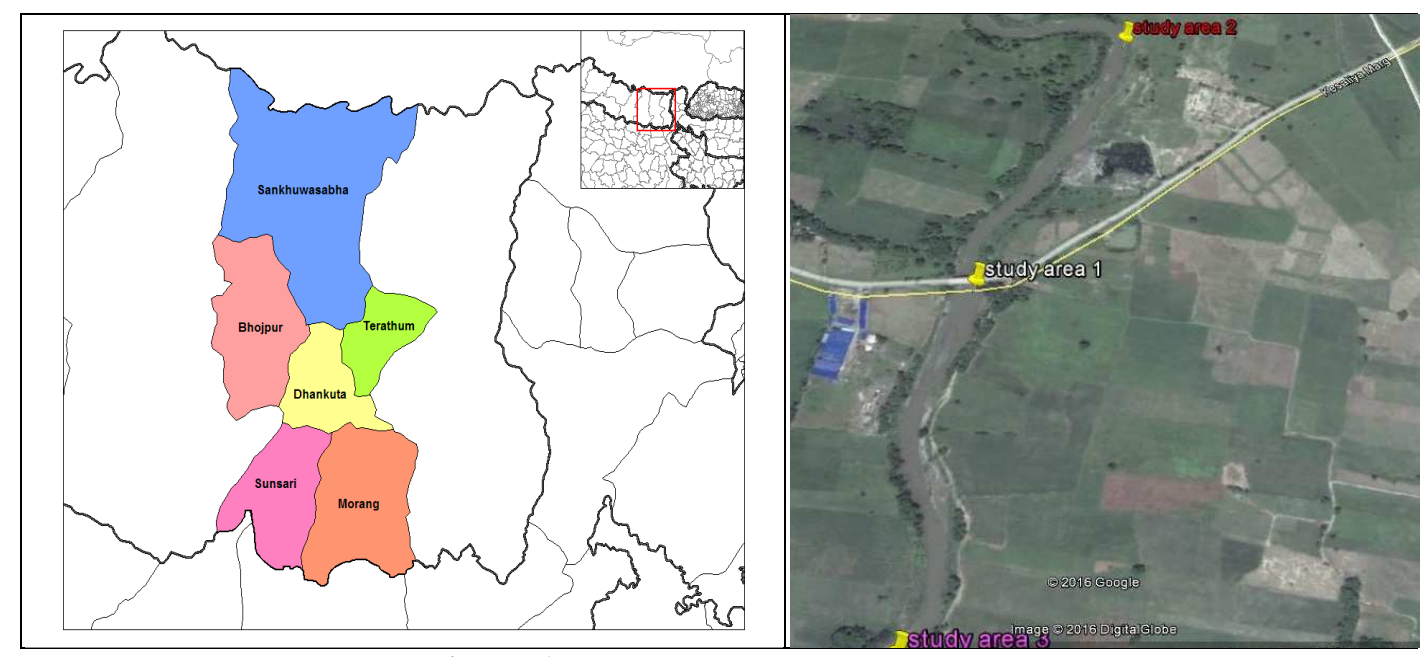

Figure 1. Study areas in Keshalia river.

Regular visits were made from $1^{\text {st }}$ October, 2015 to $30^{\text {th }}$ September, 2016 for the observation of river ecology and anthropogenic impacts in the river like disposal of industrial and domestic effluents, fishing pressure (overfishing), unconventional fishing methods (poisoning or electro fishing), soil erosion, open toilets, dumping site of waste, deposition of non degradable substances like plastics, bottles, cans etc. Observation were also made to study human impacts on river like dam and bridge constructions, irrigation channels, removal of building materials like sands, gravels, stones, soils etc., cultivated crops nearby the river and others. Information about river ecology, common anthropogenic impacts on aquatic fauna of rivers and suggestions about conservation and management strategies of water resources were received from expertise. Similarly, ideas about present and past status of fishes in the river and numbers of fishermen, rate of fish catch per week in the river, season for overfishing were obtained from fishermen. Likewise, amount of different chemical fertilizers and manures used in their agricultural fields were asked among farmers nearby the villages.

\section{Results}

The water samples of the river on August 30, 2016 had transparency $15 \mathrm{~cm}$, temperature $30^{\circ} \mathrm{C}, \mathrm{pH} 7.8$, alkalinity $80 \mathrm{mg} / \mathrm{l}$, dissolved oxygen $9.11 \mathrm{mg} / \mathrm{l}$, biological oxygen demand $31.95 \mathrm{mg} / \mathrm{l}$, dissolved carbon dioxide $110 \mathrm{mg} / \mathrm{l}$, nitrate $0.62 \mathrm{mg} / \mathrm{l}$ and phosphate $0.07 \mathrm{mg} / \mathrm{l}$.

\section{Overfishing}

Fishermen living in Biratnagar and nearby villages of the river depend on the Keshalia river. Their socio-economic condition is very low. Their economic return comes from fish 
markets. They engage full time on the river. They capture more and more fish using local gears (bamboo traps and mosquito nets), cast net, gill net, dip net (thakauli), rod and line. The rate of fishing is much faster than fishes can reproduce and replenish the water bodies with more fish. Therefore overfishing is observed in the river. Net with small mesh size not only harvest the targeted fishes but also the non targeted fishes and juveniles. This activity causes the decline of fish population in the river. So, fishes are being reduced in the river (interview with fishermen). During April, May, September and October excessive pressure of fishermen were observed in the river (Fig. 2).

\section{Poisoning}

Generally part time fishermen use the poisons especially in upper part of the river (Panbari, Yanshila, Satisale etc) for fish catching in the river. They use leaves of Sapium insigne, Agave americana which are crushed and thrown in the water. They also use bark and roots of Polygonum flacidum, P. hydropiper, Ficus pumila and Acacia pennata are also used as fish poison. All these are the common plants of terai region. They also use pesticides such as Aldrin, Thiodine, BHC, Malathion, and DDT. Poisons used in the river not only kill the targeted fish but also destroy the fries and other small fishes as well as others aquatic flora and fauna inhabiting in the river resulting imbalance the aquatic ecosystem. It also pollutes the water and become unfit for drinking, washing, irrigation and other purposes. By the process of bioaccumulation and biomagnifications through food chain, concentration of the pollutant chemicals becomes high at higher tropic level including men.

\section{Electro-fishing}

Fishermen occasionally use the electro-fishing in study area 1 for fish catching. At the time of electro-fishing, mild electricity is given in water of the river with the help of batteries and electrodes. The shock of electricity paralyzes the fishes nearby it. This makes fishermen easiest to capture the fishes which are very difficult by using cast nets.

\section{Industrial effluents}

Biratnagar is the second largest industrial area of the country. There are many industries nearby the river. Metallic industries like Aaryan wires, Jai Laxmi metatic udhog, Aarti Strips, Hulas metals, Jyoti metal udhog etc. and Shuvam sunpipe and Ganesh plastic. Similary others are sugar mills, saw mills, taxtile, flexible packaging, brick and tiles industries, biscuit industries etc. The chemicals used in and effluents coming from these industries are carried directly or indirectly into the river. Effluents of these industries may content cadmium, lead, iron, mercury, zinc, aluminium, copper, chloride, cyanide etc. These chemicals are toxic to aquatic fauna including fishes. Acidic and alkaline chemicals used in the industries influence the $\mathrm{pH}$ of water of the river. Some of these industries discharge hot water effluents directly into the river. This leads optimum temperature $\left(31^{\circ} \mathrm{C}\right)$ in the river. Mass destruction of fishes has been observed once because of toxic chemicals and hot water discharged from the industries nearby Duhabi which increase the metabolic rate and toxicity on the fishes leading to death. Mobile and grease coming from motor service centers also affect the fishes especially in its respiratory mechanism.

\section{Municipal effluents}

Biratnagar is fourth largest city of the country in term of population. It has many industries and hospitals. Biratnagar municipality discharges waste coming from the city into the river 
through many drainage channels. Organic substance deposited into the river not only increases the BOD but also makes the water putrefied. Litter like plastic, bottle, canes etc sediments on the bottom of the river resulting disturbance on the habitat of the aquatic life. It also deteriorates the quality of water. Increased total suspended particles raise the turbidity of water and also affects on the health of fishes, especially reproduction, vision and respiration. Chemicals and pathogenic microbes present in drainages introduce many adverse effects on the health of aquatic life and promoting fish diseases.

\section{Domestic sewage}

Domestic sewage contains a wide varieties of dissolved and suspended impurities containing kitchen wastes, detergents and washing powers, paints, excreta and many chemical used for cleaning the house. The accumulation of organic substances in the river leads to decrease the level of dissolve oxygen in water. Low dissolve oxygen may cause the death of aquatic fauna including fishes. The detergents, soaps and washing powers contain phosphate in large amount that increase or promote the growth of phytoplankton giving adverse affects on aquatic life. But there are no any eutrophication observed in the river. Detergents may damage the liver and kidney of the fishes. Chemicals present in the sewage may kill fishes and other aquatic life. Some of these chemicals are non degradable and may enter our bodies and give long term toxic effects on our health.

\section{Farm runoff}

Most of people around and nearby the river are farmers. Their major crops are paddy and sugarcane. They use manures like compost and chemical fertilizers like urea and DAP, each at the rate of $34 \mathrm{~kg} / \mathrm{ha}$. The fertilizers are rich with nitrogen and phosphorous which are very essential to crop growth. These nutrients are introduced into the river in the form of nitrate and phosphate resulting growth of phytoplankton and deteriorate the quality of water. Pesticides used by farmers in their fields are Noorani $(2 \mathrm{ml} / \mathrm{liter}$ of water), Rogar ( $1.5 \mathrm{ml} /$ liter of water), Phoskil ( $2 \mathrm{ml} /$ liter of water), Furadan $(1 \mathrm{~kg} / \mathrm{ha})$ etc. They also use melathione and DDT. These poisons come into the river through runoff water during rainy season. They kill not only fishes but also aquatic flora and fauna inhabiting in the river and cause loss of biological diversity of the river. These poisons introduce into human body through food chain and give long term toxic effects. The rates of accumulation of these poisons are more in higher tropic level (human). Usually, farm runoff water is acidic which lowers the PH of water (acidification) and give negative impacts on aquatic life including fishes, especially on their growth and reproduction. Pathogenic microorganisms (e.g., protozoan, virus, bacteria) and toxins also threat to fish health.

\section{Habitat destruction}

Mining of large amount of sand, gravels, stones and soil was found at the rate of 32 tractor per a day from the river to Biratnagar and nearby cities for fulfillment of building materials resulting destructing the ecological habitats, niches and breeding place of many fishes. It also increases the siltation in the river. Interference of habitats by these activities of human beings causes adverse effects on the fish health.

\section{Dumping sites}

The domestic sewage from houses and villages, and from different hospitals, pathological labs, factories, industries, causes a serious problem in pollutions. Biratnagar municipality 
collects this domestic wastage at the rate of 26 tractors/day. The wastage is carried and discharged in the different dumping sites nearby the river. One large dumping site is in my study area 2 and another dumping site in Duhabi. Dumping materials includes especially non degradable materials like plastic materials, bottle and syringes, rubbers, tin canes etc. These materials settle down on the bottom and alter the habitats of life inhabiting in the river. It also contains large amount of organic substances which alter the quality of water enhancing biological oxygen demand in the river. Thus it causes water pollution changing its water quality. Pathogens from infected materials of hospitals threat the health of aquatic life including fishes and enhance the fish diseases. These pathogens also introduce in human health through drinking water and food chain. Chemicals (especially metals like cupper, mercury, lead etc.) even though discharged in small quantities, can accumulate and becomes up to lethal limit and threat the aquatic life giving long term toxic effects on them.

\section{Soil erosion}

Soil erosion is another problem seen in the river. It increases the turbidity of water. Mechanical injury or blocking of gills from silt or other suspended material takes place in fish fauna of the river. It also causes the loss of breeding and nursing grounds of the river fish species and destruction of their food organisms.

\section{Non sanitary toilets (open toilets)}

Most of people around the river have no sanitary toilet. They defecate on either open fields or near the river. Even though Coliform bacteria are not seen, many pathogens (protozoan, helminthes, viruses and bacteria) may present which give adverse effects on the fish health. They make the water non drinkable causing many water born disease in human such as Giardiasis, Typhoid, Amoebitic dysentery and Cholera.

\section{Bridge and dam construction}

Many bridge constructions across the Budhi Khola were observed at Panbari, Itahari (across east-west highway), Duhabi (across the Dharan- Biratnagar highway) etc. My study area had also a bridge at Keshalia marg between Bhimpur VDC, Sunsari and Bramapura, Biratnagar-7, Morang. The bridges not only change the path of the river but also change the habitats of the fishes. It also causes siltation (increasing dissolved solid particles, especially silts) in the water resulting increase water temperature and decrease light penetration. This in turn effects on the rate of photosynthesis by submerged plants and phytoplanktons. This ultimately reduces the oxygen dissolved in water and threats the fishes.

\section{Acidic rain fall}

Many air pollutants like carbon dioxide, oxide of nitrogen $\left(\mathrm{NO}, \mathrm{NO}_{2}\right)$ and oxide of sulphur $\left(\mathrm{SO}_{2}, \mathrm{SO}_{3}\right)$ coming from industrial smokes and smokes coming from automobiles cause air pollution. So, first rainfall in monsoon is acidic. Even though these acidic gases come again in earth in the form of acid rain fall, the $\mathrm{pH}$ of water of the river is not so lowered $(\mathrm{pH}=7.8)$ resulting no any bad impact on the aquatic fauna including fishes.

\section{Discussion}

The anthropogenic impact in Keshalia river is very high. With increasing human population growth, urbanization, industrial effluents, domestic wastes etc. the threatened has increased on fishes. Fishermen were found to have fishing to juveniles of major carps, cat fishes and 
weed fishes using small mesh sized cast nets in the river. Unconventional fishing methods (poisoning) pollute the water and convert it unfit for drinking and irrigation. It also kills the aquatic fauna including fishes. This causes decline of fish diversity in the river. Domestic sewage, municipal effluents, industrial effluents etc bring the large amount of organic matter into the river resulting not only pollute the water but also reduce the level of dissolved oxygen in water of the river. Industrial effluents induce negative effects on the fish health and also reduce their immune competence. Animals' excreta present in river increases the percentage of ammonia which gives toxic effects on the aquatic life.

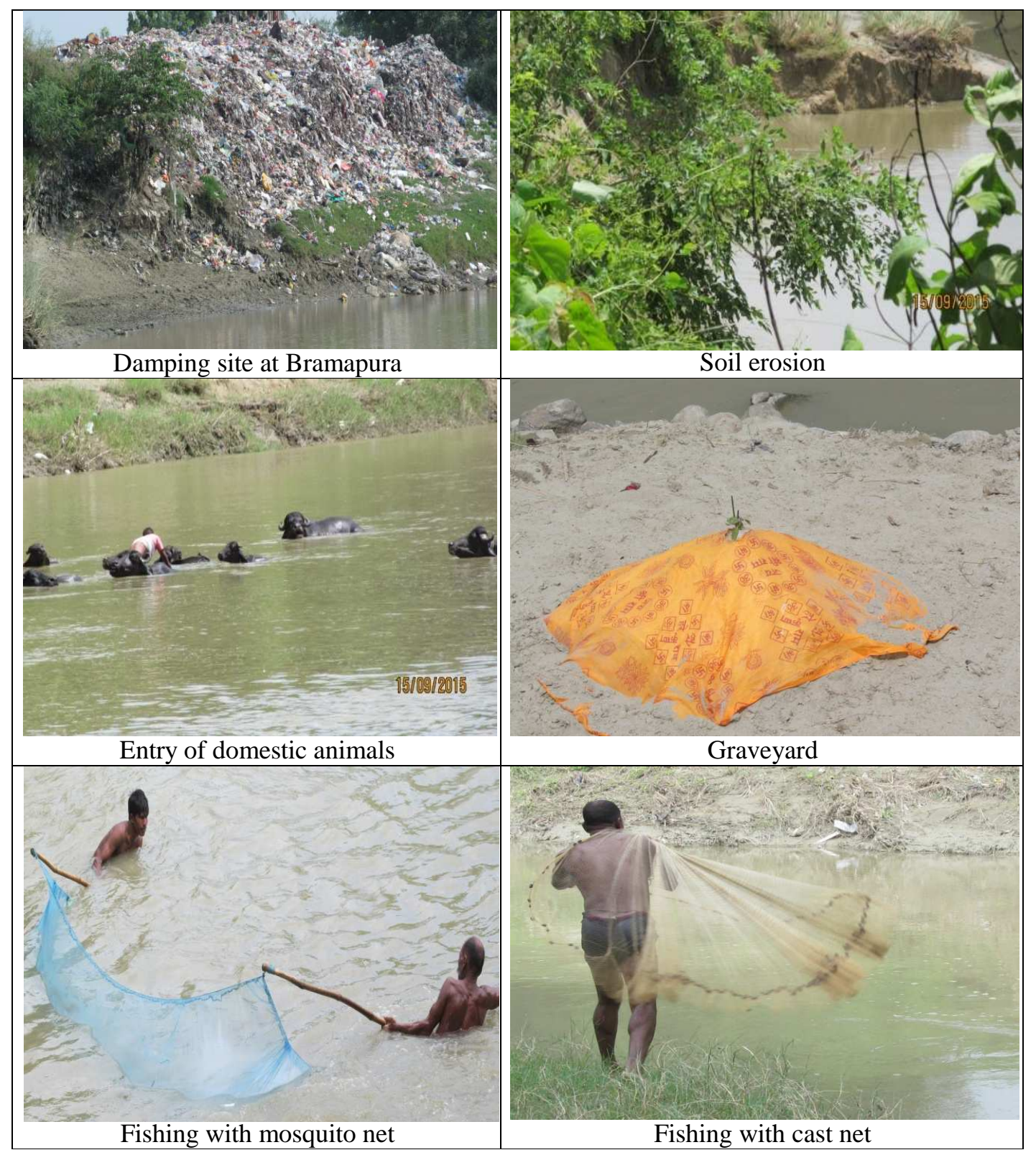

Figure 2. Anthropogenic impacts in Keshalia river. 
Human excreta may contain pathogenic protozoan, helminthes, bacteria and other microbes which give adverse effects on the health of fishes. Soil erosion due to deforestation causes siltation resulting increase turbidity of water in the river. High turbidity reduces the light available for plant growth and also damage the fish gills. Chemicals and pesticides present in sewage and runoff water induce long term toxic effects on fishes as well as human. Different gases from industries and transportation cause acid rainfall and reduce the $\mathrm{pH}$ of water. This increases the toxicity of in water. Litter coming from dumping site sediments on the bottom of the river, alter the habitats of fishes inhabiting in the river. Beside this, dam construction without fish ladder obstructs the path of migratory fishes like Bagarius bagarius. Removal of sands, gravels, soils etc. from the river not only destructs habitats of fishes but also diverse the path of the river. All these anthropogenic activities existing in the river impact on the aquatic ecosystem of the river.

\section{References}

APHA 1998. Standard methods for the examination of water and wastewater (20 ${ }^{\text {th }}$ ed.). American Public Health Association, Washington, D.C.

Bhatnagar, A., S.N. Jana, S.K. Garg, B.C. Patra, G. Singh \& U.K. Barman 2004. Water quality management in aquaculture. In: Course Manual of Summerschool on Development of Sustainable Aquaculture Technology in fresh and saline waters. CCS Haryana Agricultural, Hisar, India. pp. 203-210.

Bukola, D., A. Zaid, E.I. Olalekan \& A. Falilu 2015. Consequences of anthropogenic activities on fish and the aquatic environment. Poultry Fisheries and Wildlife Sciences 3: 138. DOI: $10.4172 / 2375-446 X .1000138$.

Cowx, I.G. 2002. Analysis of threats to freshwater fish conservation: past and present challenges. In: Conservation of freshwater fishes: Options for the future (Eds. M.J. Collares-Pereira, I.G. Cowx \& M.M. Coelho). Fishing News Books, Blackwell Science, Oxford. pp. 201-220.

Ekubo, A.A. \& J.F.N. Abowei 2011. Review of some water quality management principles in culture fisheries. Research Journal of Applied Sciences, Engineering and Technology 3(2): 1342-1357.

Gurung, T.B. 2012. Native fish conservation in Nepal: Challenges and opportunities. Nepalese Journal of Biosciences 2: 71-79.

Laë, R. 1995. Climatic and anthropogenic effects on fish diversity and fish yields in the Central Delta of the Niger River. Living Resources 8: 43-58.

Puff, N.L., J.D. Allan, M.B. Bain, J.R. Karr, K.L. Prestegaard, B.D. Richter, R.E. Sparks \& J.C. Stromberg 1997. The natural flow regime, a paradigm for river conservation and restoration. Bioscience 47: 769-784. 